\title{
Mobile learning: perspectives
}

\author{
Juan Carlos Torres Diaz', Alfonso Infante Moro² and Pablo Vicente Torres Carrión ${ }^{3}$ \\ 1. Private Technical University of Loja (UTPL), Ecuador | jctorres@utpl.edu.ec \\ Submitted in: September 2013 \\ 2. University of Huelva (UHU), Spain | alfonso.infante@uhu.es \\ Accepted in: February 2014 \\ 3. Private Technical University of Loja (UTPL), Ecuador | pvtorres@utpl.edu.ec \\ Published in: January 2015
}

\section{Recommended citation}

Torres, J.C., Infante, A. \& Torres, P.V. (2015). Mobile learning: perspectives. RUSC. Universities and Knowledge Society Journal, 12(1). pp. 38-49. doi http://dx.doi.org/10.7238/rusc.v12i1.1944

\begin{abstract}
From a technical perspective, the future of learning is defined by four axes around which technological and methodological efforts revolve. These axes are mobility, interaction, artificial intelligence and technologybased resources such as augmented reality and games applied to learning. Combining them means creating a model of mobile, interactive and intelligent scenarios that take advantage of the spaces and times available to the learner. The various technologies are already available yet used separately in different educational experiences. It is therefore crucial to combine and integrate them into didactic models wherein the learning attained by students is significant. This article discusses these technologies and proposes an integrative model that enables a framework of reference for didactic work to be established. It concludes by highlighting the need to experiment with technologies and to apply the results to teaching-learning models using alternative interaction schema, and the urgency of having intelligent tutoring systems to make tutoring available on a massive scale.
\end{abstract}

\section{Keywords}

mobile learning, artificial intelligence, social networks, learning models, technology

\section{Aprendizaje móvil: perspectivas}

\section{Resumen}

El futuro del aprendizaje, desde una perspectiva técnica, está integrado por cuatro ejes que lo definen y sobre los que se articulan esfuerzos tecnológicos y metodológicos. Estos ejes son: la movilidad, la interacción, la inteligencia artificial y recursos basados en tecnología como la realidad aumentada y los juegos aplicados al aprendizaje. Su combinación supone la creación de un modelo de escenarios móviles, interactivos e inteligentes que aprovechan todos los espacios y tiempos disponibles para el aprendiente. Las distintas tecnologías, cada una por su lado, ya están disponibles y son utilizadas en diversas experiencias educativas; lo que se hace necesario es la conjugación de estas a través de modelos didácticos en los que el aprendizaje alcanzado por los estudiantes sea significativo. En este artículo se discuten estas tecnologías y se plantea un modelo de integración que posibilita el establecimiento de un marco referencial de trabajo didáctico. Se concluye la necesidad de experimentar tecnologías y plasmar los resultados en modelos de enseñanza-aprendizaje que utilicen esquemas de interacción alternativos y la urgencia de contar con sistemas tutoriales inteligentes para masificar la tutoría.

\section{Palabras clave}

aprendizaje móvil, inteligencia artificial, redes sociales, modelos de aprendizaje, tecnología 


\section{Mobility as a platform}

We live in an era in which more and more information and knowledge are becoming available in less time (Kurzweil, 2005), technological developments are faster than pedagogical developments and, generally speaking, technology is what ends up determining many of the lines of research to pursue. Based on device sales indicators, The Horizon Report (Johnson, Smith, Willis, Levine, \& Haywood, 2011) put mobile computing on the near term horizon, due in part to the increase in mobile access plans and the development of mobile learning within reach of all students. The growth in rates of access to the Internet via mobile devices is setting a trend that actually runs counter to the classic disadvantages experienced by certain social and ethnic groups.

Mobile devices offer the advantage of integrating several technologies into a single unit; in the field of education, this represents a set of possibilities that have had a major impact (Low, 2006). They offer the possibility of having tools and resources available anytime, anywhere, thereby creating a combination of possibilities that, properly exploited, can improve learning results. Applying the concept of mobility to education has the power to make processes ubiquitous and to combine formal learning that takes place in a classroom with informal learning that occurs in social networks, thus breaking structures and concepts and paving the way for a series of innovations, the effects of which need to be experienced.

In addition to academic applications is the Web 2.0 phenomenon, which has caused the mobile wave to spread across the globe; Internet users upload information to share with others in their social networks, they interact with each other in those social networks and they collaboratively construct knowledge as constituent parts of a collective intelligence in which leisure and entertainment take up a considerable amount of time.

According to Low (2006), learning via mobile devices facilitates the students'activities, which the author divides into four categories:

1. Students are capable of creating and capturing their own content.

2. Students can access educational resources.

3. Students use digital devices to process learning stimuli.

4. Students communicate with their peers and tutors, establishing relationships that are useful to learning.

The fourth category refers to the interaction that occurs among members of a learning network, which includes lecturers and students. On the one hand, the relationships enable the development of social learning (Siemens, 2005; Sangrà \& Wheeler, 2013), wherein the community's positive behaviours are imitated and, on the other, the development of a social constructivist environment, wherein the social context is the cornerstone for the construction of learning.

Mobile devices improve communication possibilities and facilitate social interaction, collaboration and learning (Low \& O'Connell, 2006). Likewise, they improve educational dynamics by increasing communication possibilities (Liu \& Kao, 2007). However, it is crucial to develop experimental models that use these technologies, which are capable of facilitating positive learning results. Theoreticians in this field have suggested that further research should be conducted on the application of mobile computing to education and the resultant findings documented (Cobcroft, Towers, Smith, \& Bruns, 2006; Torrisi-Steele, 2006). While there is a considerable number of studies and accounts of experiences on the various areas of mobile learning, it is essential to consolidate that knowledge and apply it to reference models, wherein both the use and the target results are sought. 


\section{Socialisation and learning}

Informal learning refers to learning based on day-to-day experience (Siemens, 2005); we constantly learn from mistakes, experience, context, etc. It is not usual for informal learning to occur within a structured setting such as a classroom. Informal learning has its origin in the social learning theory of Rotter (1954), which indicates that a person tends to learn from a community those behaviours that he or she considers positive and useful. The members of a community seek out those situations or information that add value to their goals or arouse a particular interest. Besides the distinction between egocentric and object-centric social networks (Stutzman, 2007), interaction generally occurs around content and topics; for content, it occurs indistinctively around photos, videos and other media, and, in the words of Llorens and Capdeferro (2011), "text, voice, music, graphics, photos, animation and video are combined to promote users' thinking and creativity when undertaking high-level tasks"; for topics, interaction occurs around the interest in giving one's opinion on or finding out about the community's criteria on specific topics (Torres-Diaz, Jara, \& Valdiviezo, 2013).

The development and spread of mobile devices have been extraordinary and have fostered the emergence of socially oriented complementary technologies. The advantage of Web 2.0 and social networks is that the users (students in this instance) can create, share, comment on and improve content in a collaborative and inclusive spiral, where they share and learn. Moreover, these activities can take place in a ubiquitous environment thanks to mobile technology (Torres-Diaz et al., 2013). Mobility encourages interaction because of its ubiquity advantage. Today, it is usual for users to interact when on the move and not necessarily at any specific time. This makes day-to-day learning a way of life. Using social networks for learning implies learning formal content in an informal manner; content creation, interaction and learning occur on academic topics that form part of the students' curricula.

The fact that new generations have adopted informal learning as one of the natural actions that they undertake at any time is beyond question (Llorens \& Capdeferro, 2011). Therefore, academia has the task of transferring its offerings to these new scenarios - with which students are familiar and within which they feel comfortable - and taking advantage of the spaces that social networks generate and, above all, of the methods employed to interact and learn collaboratively.

\section{Artificial intelligence: recommender systems}

An emergent field of artificial intelligence is recommender systems (RSs), which suggest topics, activities or products in accordance with the user's preferences (Velez-Langs \& Santos, 2006). An RS works in two ways: by predicting that a user will like a certain product or by recommending a product in accordance with the user's preferences (Sarwar, Karypis, Konstan, \& Riedl, 2001). Similarly, Peña \& Riffo (2008) define RSs as an information-filtering technology that provides personalised recommendations of products that a user requires; these supply a useful mechanism for suggesting people, services or objects of interest in a specific context (Alejandres Sánchez, González Serna, \& Vargas Govea, 2011). RSs are the future of artificial intelligence; in the field of education, they provide the tutoring component and help lecturers with their task of recommending resources and activities. Their potential is so vast that they are considered a fundamental element for the future of massive open online courses (MOOCs).

There are various studies in which RSs are an integral part of academic processes. Casali, Gerling, Deco, and Bender (2010) created an intelligent system that helps users find digital educational resources that are best suited 
to their profiles. In their study, they used the multi-agent architecture proposed by Gerling (2009), which has the following levels: interface agent, semantic refining agent, user profile agent, search engine agent, mediating agent and recommender agent. García Salcines, Romero Morales, Ventura Soto, and De Castro Lozano (2008) have proposed the Continuous Improvement of e-Learning Courses Framework (CIECoF) as a collaborative RS applied to education, the main aim of which is to help lecturers improve online courses; they apply distributed data mining to a client-server architecture with $N$ clients, who use the same association rule mining algorithm in a local environment, taking the history of the students' use of an online course as the input.

In virtual learning environments (VLEs), Valdiviezo, Santos, and Boticario (2010) have expounded the application of unsupervised learning techniques to identify common patterns of interaction with the forums available on an OpenACS/dotLRN course, promoting the definition of recommendations that help to improve the students' learning experience. The cases presented above are just a small sample of the breadth of research work conducted on the application of artificial intelligence to educational resources and processes.

\section{Augmented reality}

This concept is defined as a reality that goes beyond the reality we are normally able to perceive through our senses; augmented reality adds a layer of contextual information to the real world (Johnson et al., 2011). This layer may contain any type of computer-generated information. Azuma, Behringer, Feiner, Julier, and Macintyre (2001) have defined augmented reality as an amalgamation of graphics, vision and multimedia to improve the user's perception of the real world by adding virtual information.

Augmented reality applications have features that may be static, dynamic, interactive or autonomous, which can be viewed on a computer screen or a specially designed viewing device, or via images projected in the form of a hologram (Thornburg \& Mahoney, 2009). This enables users (students) to go into a real world that has an additional layer of information. This layer offers the possibility of moulding or nuancing reality through digital elements to enhance perception and, in general, to improve learning.

In the field of education, this technology promises significant contributions; ideally, its applicability would be oriented towards studying hard-to-access or danger-ridden knowledge areas.

Augmented reality is an active, not a passive technology; students can use it to construct new understanding based on interactions with virtual objects that bring underlying data to life. Dynamic processes, extensive datasets, and objects too large or too small to be manipulated can be brought into a student's personal space at a scale and in a form easy to understand and work with (Johnson et al., 2011).

The noted interaction and autonomy characteristics are especially significant in the field of education, where the advantage over traditional learning methods resides in the fact that students are able to see, hear and manipulate information (Liarokapis \& Anderson, 2010); it is also possible to repeat certain parts of a process as many times as necessary without consuming materials or running risks that an experiment may involve. Liarokapis and Anderson (2010) have underscored four potential benefits of augmented reality in the field of education: 
- Multi-modal visualisation of difficult theoretical concepts.

- Practical exploration of the theory through tangible examples.

- Natural interaction with multimedia representations of teaching material.

- Effective collaboration and discussion amongst the participants.

\section{Game-based learning}

Game-based learning is defined as the use and design of game elements in "non-game" environments (Deterding, Khaled, Nacke, \& Dixon, 2011). Applying games to education can be analysed from motivational, cognitive and sociocultural perspectives (Jong, Shang, Lee, \& Lee, 2008). In the first instance, Prensky (2003) has contrasted the learning success that can be attained by motivated students and the minimally motivating aspect of the content delivered to them. Many studies have related motivation with learning, and most are based on the proposal by MaIone (1980), in which the author underscores seven factors that generate intrinsic motivation: challenge, curiosity, control, fantasy, competence, cooperation and recognition. These factors enable the user to participate actively, which coincides with the tendency to shift from an instructive model to a constructivist model, wherein the student plays a lead role.

Regarding the cognitive perspective of the use of games, there are two ways in which games can be applied to higher education. First, games are used with broader aims, wherein their use has greater importance within a set of learning activities; they are, therefore, a means of acquiring knowledge and certain skills. Second, games are used in specific situations, wherein they make a complementary contribution to course content (Johnson et al., 2011).

\section{Towards techno-pedagogical integration}

The integration of technology into education has led to various studies and reference models being conducted and developed. These have put order into scholarly work and point to paths that ought to be pursued in the process of implementing educational technology (Park, 2011; Kearney, Schuck, Burden, \& Aubusson, 2012; Castaño-Muñoz, Duart, \& Sancho-Vinuesa, 2013; Cataldi \& Cabero Almenara, 2006; Junco \& Cotten, 2011). In that process, it has been established that learning is affected by the tools used, and likewise, that learning tools are modified by the way in which they are used (Kearney et al., 2012). This reflects a profound relationship between concepts and means, and the need for a systemic view of teaching-learning models.

A conceptual model that situates mobile learning from different perspectives is relevant and necessary to guide formative actions in specific contexts. In an initial effort to provide mobile learning with a platform of analysis, Park (2011) has proposed a four-type categorisation of mobile learning technologies. In Figure 1, the x-axis is divided at the ends into individualized activity $(-x)$ and socialized activity $(+x)$; on the $y$-axis, it is assumed that activities can be of low transactional distance $(+y)$ and high transactional distance $(-y)$, where high or low transactional distance is when the activities are considered to require a highly structured academic programme or not.

Danaher, Gururajan, \& Hafeez-Baig (2009) have proposed a model comprising three principles: participation, presence and flexibility. These principles are employed as strategies to evaluate pedagogical innovations in mobile learning environments. Kearney et al. (2012) have proposed another model in which three elements intervene: 
authenticity, collaboration and personalisation. In that model, mobility is approached from a pedagogical perspective embedded in a space-time context. A model that goes beyond conceptual aspects and takes usability into account is the one by Vavoula \& Sharples (2009), which has a three-level evaluation framework comprising a micro level, a meso level and macro level examining individual activities, the learning experience and institutional impact, respectively. However, there are two broader models that consider technical elements of mobile devices. One is by Koole (2009), which is based on a systemic perspective that enables learning to be situated in the best way possible by taking different contexts into account, and the other is by Ozdamli (2012), which comprises four components: integration of tools, pedagogical approaches, assessment techniques and teacher training. In this model, mobile tools provide support for communication among students, teachers and resources; the pedagogical approaches include constructivism, active learning, collaborative learning and blended learning. The assessment techniques are integral, and among them are computer-based assessment, tutor assessment, self-assessment and peer assessment.

Figure 1. Working framework for mobile learning (Park, 2011)

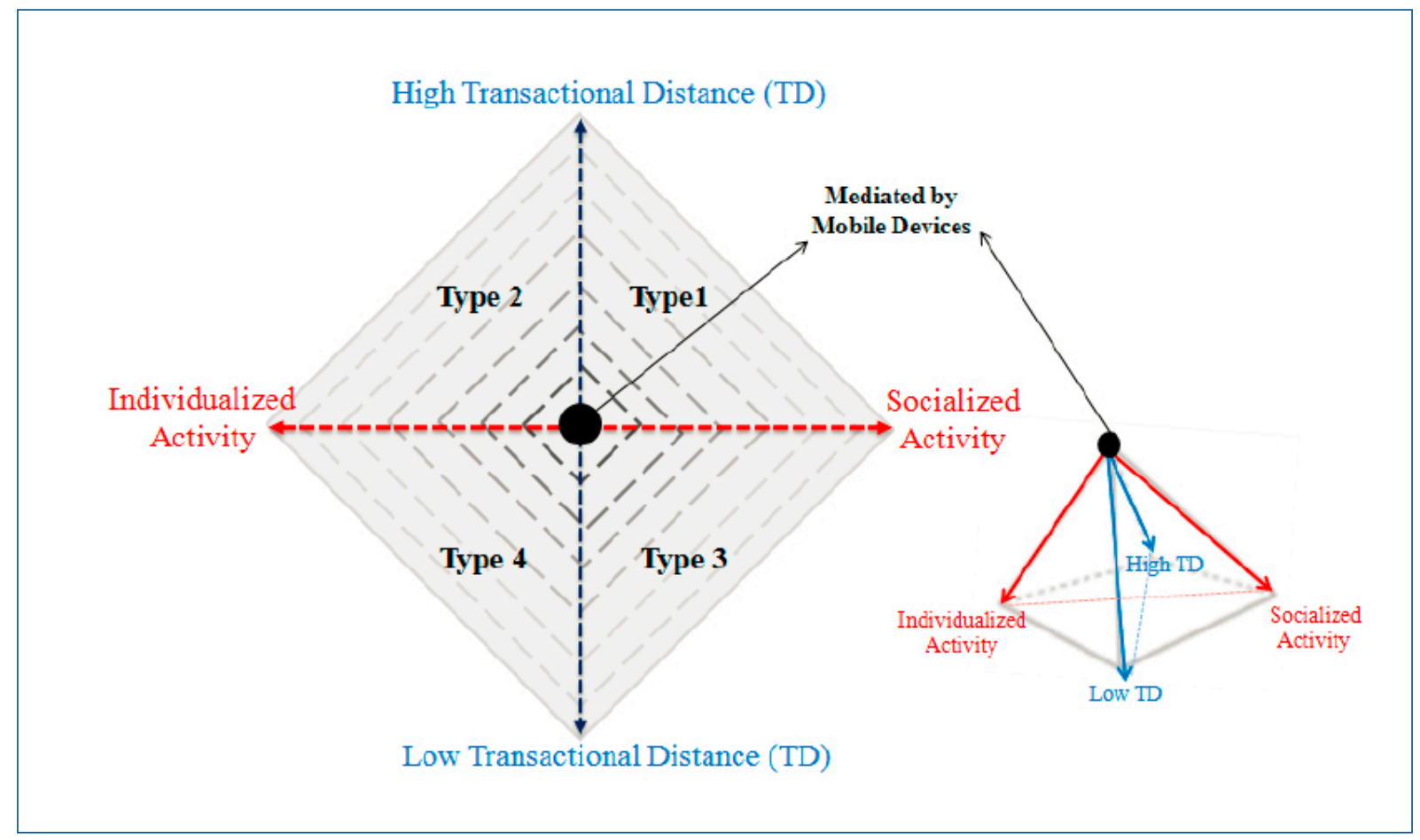

In this article, we propose a model that is similar to the one by Kearney et al. (2012) as regards the collaboration and personalisation components; however, the proposed model is more complete because it articulates elements that, taken to a virtual platform, enable interactive and intelligent mobile learning scenarios to be configured, wherein students see and feel an environment adapted to their needs and learning styles.

The first element of the model is mobility, the greatest contribution of which is its ability to break down the barriers of space and time as it enables permanent contact between the actors of a teaching-learning process (see Figure 2).

The second component of this schema is socialisation, on which a universe of relationships is built. These relationships represent the richness and potential of a learning process. In this component, it is crucial to consider the need to combine formal and informal learning as it is the latter that takes place in social networks, and it usually 
does so through leisure or entertainment content. The challenge is to apply the tools and methods used in social networks to the formal content imparted in the education system.

Figure 2. Integration schema

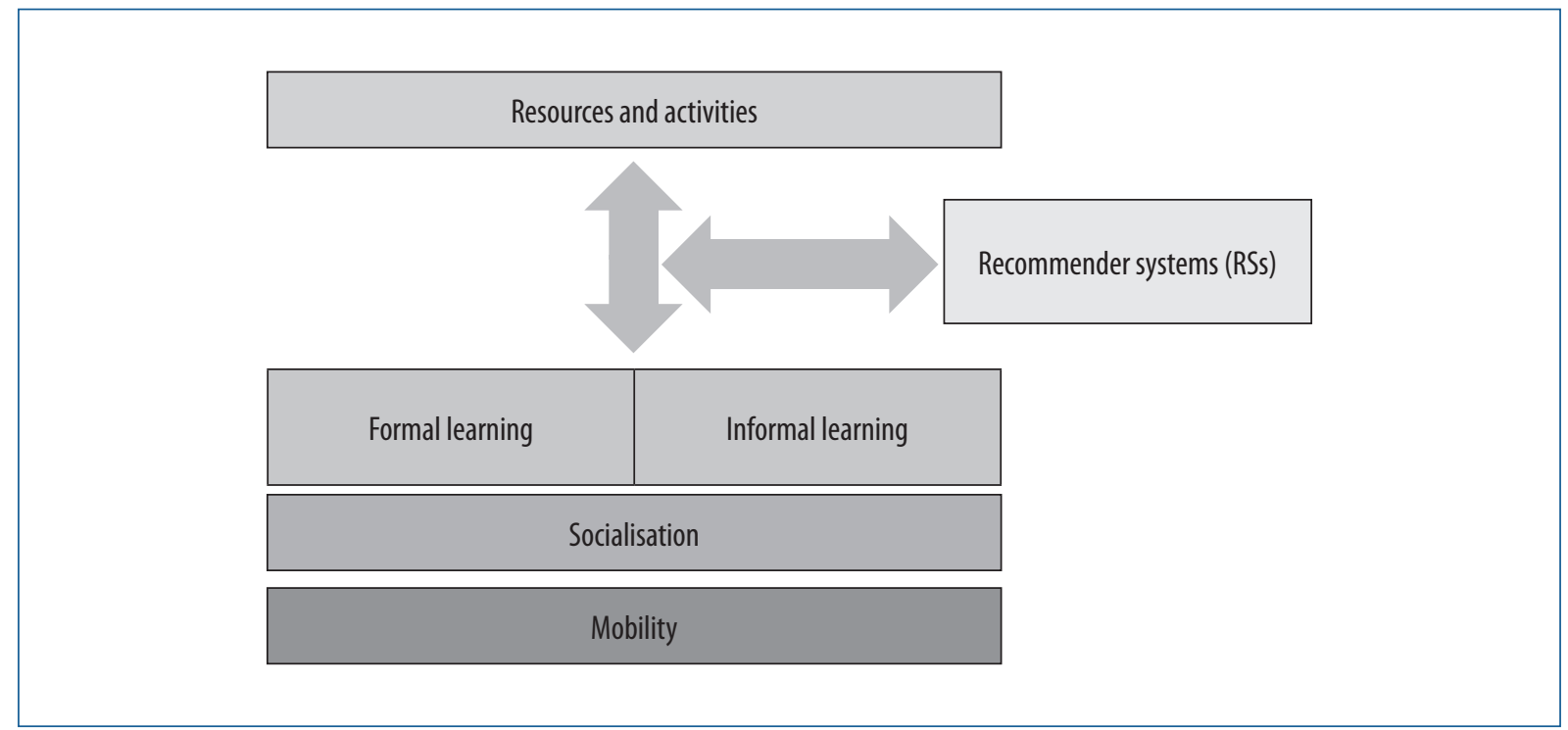

The component that distinguishes our model from those currently applied is artificial intelligence, which performs a support role via RSs, which are charged with modelling the way in which students learn, and with adapting means and resources to support their learning; it performs a virtual tutor role, the purpose of which is to guide and/or recommend actions that learners should take.

Learning activities, which are part of course design, generally concern educational resources; these take advantage of the potential of technologies and improve assimilation levels. Among these technologies are augmented reality and computer games, which enable learners to improve their assimilation levels; they make content clear and their multimedia aspect - which students are used to - makes them attractive.

The relationships established between the components are based on the assumption of ubiquity, and they occur in two respects. The first set of relationships implies that interaction is achieved through resources and learning activities; this, of course, is defined in the instructional design, and it breaks traditional schemata, uses novel didactic strategies and proposes that formal learning should become a way of life wherein informal learning methods are used.

The second set of relationships is defined by the learner's interaction with technology. The user's actions in a VLE are logged and a profile of learning preferences and patterns is developed; this serves as the basis on which certain activity and resource recommendations are made (see Figure 3).

Three elements typical of every system intervene in this relationship. The first is input, which is formed by the users' activities in the learning environment; in other words, their preferences and actions are logged, as are the educational materials they use, the learning activities they undertake, the time they spend on them, etc.

The second is processing, which is executed on input data. Artificial intelligence algorithms map out learning paths based on patterns and preferences; these paths consider the resources and activities that are best suited to the student's particular learning style; the determination of learning paths, patterns and preferences is dynamic, as 
it is constructed in a permanent, iterative manner by constantly reading input data, thus enabling the system to evolve and learn.

The third is the transformation that the VLE undergoes by adapting itself to the students' needs and styles. This adaptation is directed by the results obtained from processing the learners' data.

Figure 3. Schema of relationships in an RS

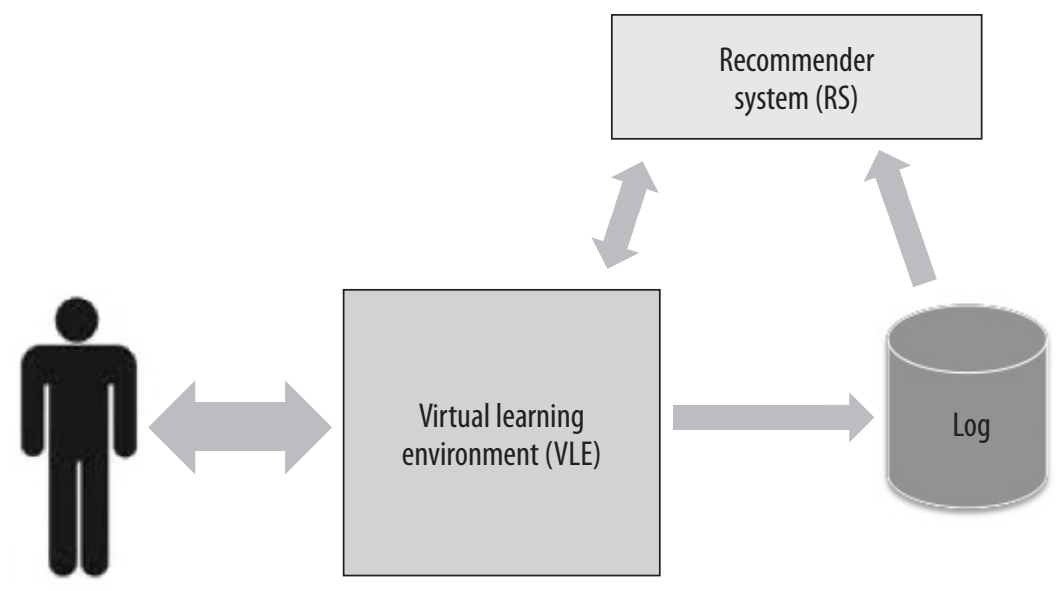

\section{Conclusions}

It is possible to foresee an imminent future dominated by the inclusion of technological components, wherein two areas stand out. The first is the development of the ubiquity concept, strengthened by the development of mobile technology. This area requires work to be done on developing technologies that take advantage of mobile potential, and on adapting methods to new forms of interaction and learning, creating and experimenting with teachinglearning models not only as technological innovation proposals, but also as alternatives capable of improving the students' content assimilation levels.

The second is the automation of teaching in terms of tutoring and student support. Automated teaching systems are being developed and driven by the emergence of $\mathrm{MOOCs}$, the mass access feature of which requires an important contingent of tutors; that need could be met by the development of this technology. For artificial intelligence, education is a vast field of experimentation, and the first advances can already be seen. The future of VLES entails intelligent components charged with tutoring and learning personalisation processes. There is an urgent need to experiment with these technologies and to have an effective cross-disciplinary methodological axis that ensures suitable levels of learning. 


\section{References}

Alejandres Sánchez, H. O., González Serna, J. G., \& Vargas Govea, B. A. (2011). Sistemas de recomendación en ambientes organizacionales: estado del arte y tendencias futuras. In IX Congreso nacional sobre innovación y desarrollo tecnológico (pp. 428-434). Mexico.

Azuma, R., Behringer, R., Feiner, S., Julier, S., \& Macintyre, B. (2001). Recent Advances in Augmented Reality. IEEE Computer Graphics And Applications, 21(6), 34-47. doi http://dx.doi.org/10.1109/38.963459

Casali, A., Gerling, V., Deco, C., \& Bender, C. (2010). Sistema inteligente para la recomendación de objetos de aprendizaje. Generación Digital, 9(1), 88-95.

Castaño-Muñoz, J., Duart, J. M., \& Sancho-Vinuesa, T. (2013). The Internet in face-to-face higher education: Can interactive learning improve academic achievement? British Journal of Educational Technology. doi http://dx.doi. org/10.1111/bjet.12007

Cataldi, Z., \& Cabero Almenara, J. (2006). Los aportes de la tecnología informática al aprendizaje grupal interactivo. Pixel-Bit. Revista de Medios y Educación, 27, 115-130.

Cobcroft, R., Towers, S., Smith, J., \& Bruns, A. (2006). Learning in review: Opportunities and challenges for learners, teachers, and institutions. In Learning on the Move. Brisbane, Australia: OLT. Retrieved from http://eprints.qut.edu. au/5399/1/5399.pdf

Danaher, P., Gururajan, R., \& Hafeez-Baig, A. (2009). Transforming the practice of mobile learning: promoting pedagogical innovation through educational principles and strategies that work. In H. Ryu \& D. Parsons (Eds.), Innovative mobile learning: Techniques and technologies (pp. 21-46). Hershey: IGI Global.

Deterding, S., Khaled, R., Nacke, L. E., \& Dixon, D. (2011). Gamification: Toward a Definition. In Proceedings of the 2011 Workshop Gamification: Using Game Design Elements in Non-Game Contexts. New York, NY: ACM. Retrieved from http://gamification-research.org/wp-content/uploads/2011/04/02-Deterding-Khaled-Nacke-Dixon.pdf

García Salcines, E., Romero Morales, C., Ventura Soto, S., \& De Castro Lozano, C. (2008). Sistema recomendador colaborativo usando minería de datos distribuida para la mejora continua de cursos e-learning. IEEE-RITA, 3(1), 19-30.

Gerling, V. (2009). Un sistema inteligente para asistir la búsqueda personalizada de objetos de aprendizaje. Universidad Nacional de Rosario. Retrieved from https://www.fceia.unr.edu.ar/lcc/t523/uploads/21.pdf

Johnson, L., Smith, R., Willis, H., Levine, A., \& Haywood, K. (2011). The horizon report. Media. Austin, TX: The New Media Consortium

Jong, M., Shang, J., Lee, F.-L., \& Lee, J. (2008). Harnessing computer Games in Education. Journal of Distance Education Technologies, 6, 1-9. doi http://dx.doi.org/10.4018/jdet.2008010101

Junco, R., \& Cotten, S. (2011). Perceived academic effects of instant messaging use. Computers \& Education, 56(2), 370-378. doi http://dx.doi.org/10.1016/j.compedu.2010.08.020

Kearney, M., Schuck, S., Burden, K., \& Aubusson, P. (2012). Viewing mobile learning from a pedagogical perspective. Research in Learning Technology, 20. doi http://dx.doi.org/10.3402/rlt.v20i0/14406

Koole, M. L. (2009). A model for framing mobile learning. In M. Ally (Ed.), Empowering learners and educators with mobile learning (pp. 25-47). Athabasca: Athabasca University Press.

Kurzweil, R. (2005). The singularity is near: when human transcend biology. New York, NY: Penguin Group.

Liarokapis, F., \& Anderson, E. F. (2010). Using Augmented Reality as a Medium to Assist Teaching in Higher Education. In Eurographics 2010. Norrköping, Sweden: Eurographics Association. Retrieved from http://www.soi.city. ac.uk/fotisl/publications/EG2010.pdf 
Liu, C.-C., \& Kao, L.-C. (2007). Do handheld devices facilitate face-to-face collaboration? Handheld devices with large shared display groupware to facilitate group interactions. Journal of Computer Assisted Learning, 23, 285-299. doi http://dx.doi.org/10.1111/j.1365-2729.2007.00234.x

Llorens, F., \& Capdeferro, N. (2011). Facebook's potential for collaborative learning. RUSC. Universities and Knowledge Society Journal, 8(2), 31-45. doi http://dx.doi.org/10.7238/rusc.v8i2.963

Low, L. (2006). Connections: Social and mobile tools for enhancing learning. The Knowledge Tree journal, (12), 1-10. Retrieved from http://robertoigarza.files.wordpress.com/2008/10/art-social-and-mobile-tools-for-enhancinglearning-low-2006.pdf

Low, L., \& O'Connell, M. (2006). Learner-centric design of digital mobile learning. En: Learning on the Move. Brisbane, Australia: OLT. Retrieved from http://www.academia.edu/941536/Learner-entric_design_of_digital_mobile_ learning

Malone, T. (1980). What makes things fun to learn? A study of intrinsically motivating computer games. Palo Alto, CA: Xerox. Ozdamli, F. (2012). Pedagogical framework of m-learning. Procedia - Social and Behavioral Sciences, 31, 927-931. doi http://dx.doi.org/10.1016/j.sbspro.2011.12.171

Park, Y. (2011). A Pedagogical Framework for Mobile Learning: Categorizing Educational Applications of Mobile Technologies into Four Types. International Review of Research in Open and Distance Learning, 12(2), 78-102.

Peña, F., \& Riffo, R. (2008). Revisión, selección e implementación de un algoritmo de recomendación de material bibliográfico utilizando tecnología \{j2EE\}. Concepción, Chile: Universidad del Bío-Bío. Retrieved from http:// cybertesis.ubiobio.cl/tesis/2008/riffo_r/doc/riffo_r.pdf

Prensky, M. (2003). Digital Game-Based Learning. ACM Computers in Entertainment, 1(1), 1-4. doi http://dx.doi. org/10.1145/950566.950596

Rotter, J. B. (1954). Social learning and clinical psychology. New York, NY: Prentice-Hall. doi http://dx.doi. org/10.1037/10788-000

Sangrà, A., \&Wheeler, S. (2013). New informal ways of learning: Or are we formalising the informal? RUSC. Universities and Knowledge Society Journal, 10(1). doi http://dx.doi.org/10.7238/rusc.v10i1.1689

Sarwar, B., Karypis, G., Konstan, J., \& Riedl, J. (2001). Item-Based Collaborative Filtering Recommendation Algorithms. In Proceedings of the 10th international conference on World Wide Web (pp. 285-295). New York, NY: ACM. doi http://dx.doi.org/10.1145/371920.372071

Siemens, G. (2005). Connectivism: A Learning Theory for the Digital Age. International Journal of Instructional Technology and Distance Learning, 2(1), 3-10.

Stutzman, F. (2007). Social network transitions (Web log post). Retrieved from http://chimprawk.blogspot. com/2007/11/social-network-transitions.html

Thornburg, D., \& Mahoney, S. (2009). From Cyberspace to Augmented Reality: Education's Ongoing Journey on the Internet. Retrieved from http://www.tcse-k12.org/pages/AugmentedReality.pdf

Torres-Diaz, J. C., Jara, I., \& Valdiviezo, P. (2013). Integración de redes sociales y entornos virtuales de aprendizaje. Revista de educación a distancia, 35. Retrieved from http://www.um.es/ead/red/35/torres_et_al.pdf

Torrisi-Steele, G. (2006). The making of m-learning spaces. OLT Conference 2006 - Learning on the move. Retrieved from http://research-hub.griffith.edu.au/display/n95dad4ac8b8d95f4f577abc99ef26b48

Valdiviezo, P., Santos, O., \& Boticario, J. G. (2010). Aplicación de métodos de diseño centrado en el usuario y minería de datos para definir recomendaciones que promuevan el uso del foro en una experiencia virtual de aprendizaje. RIED, 13(2), 237-264.

RUSC Vol. 12 No 1 | Universitat Oberta de Catalunya and University of New England | Barcelona, January 2015 @ Juan Carlos Torres Diaz, Alfonso Infante Moro and Pablo Vicente Torres Carrión |@by FUOC, 2015 | Mobile learning: perspectives 
Vavoula, G., \& Sharples, M. (2009). Meeting the challenges in evaluating mobile learning: a 3-level evaluation framework. International Journal of Mobile and Blended Learning, 1(2), 54-75. doi http://dx.doi.org/10.4018/ jmbl.2009040104

Velez-Langs, O., \& Santos, C. (2006). Sistemas recomendadores: Un enfoque desde los algoritmos genéticos. Gestión y Producción, 1(9), 23-31.

\section{About the authors}

Juan Carlos Torres Diaz

jctorres@utpl.edu.ec

Researcher, Department of Computer Sciences, Private Technical University of Loja (UTPL), Ecuador

His work focuses on the application of technology to educational processes, and particularly on social networks applied to learning, and learning analytics.

Universidad Técnica Particular de Loja (UTPL)

San Cayetano, s/n

Loja

Ecuador

\section{Alfonso Infante Moro}

alfonso.infante@uhu.es

Lecturer, Department of Financial Economics, Accounting and Operations Management,

University of Huelva (UHU), Spain

He holds a doctorate in Education and Business Sciences (UHU). He is a lecturer in the Department of Financial Economics, Accounting and Operations Management at UHU and a member of the Government of Andalusia's GITCE research group. He was the director of the Virtual Teaching Unit at UHU from 2003 to 2013. He is the editor of Revista Campus Virtuales. He has taken part in various research projects funded by the European Union on online learning and information and communication technologies (ICTS), as well as others funded by Spain's national and autonomous governments.

Universidad de Huelva

Departamento de Economía Financiera, Contabilidad y Dirección de Operaciones

Campus de La Merced

Plaza de la Merced, 11

21071 Huelva

Spain 
Pablo Vicente Torres Carrión

pvtorres@utpl.edu.ec

Researcher and Lecturer, Private Technical University of Loja (UTPL), Ecuador

He is a researcher into inclusive education and human-computer interface $(\mathrm{HCl})$ teaching strategies. He holds a bachelor's degree in IT Systems and Computing (UTPL), a master's degree in Intelligence Development and a master's degree in Social Media and Education in Digital Environments.

Universidad Técnica Particular de Loja (UTPL)

Departamento de Informática y Electrónica

Sección de Investigación en Inteligencia Artificial

San Cayetano, s/n

Loja

Ecuador

(c) SOMIE RIGHIS RESERVED
The texts published in this journal are - unless indicated otherwise - covered by the Creative Commons Spain Attribution 3.0 licence. You may copy, distribute, transmit and adapt the work, provided you attribute it (authorship, journal name, publisher) in the manner specified by the author(s) or licensor(s). The full text of the licence can be consulted here: <http://creativecommons.org/licenses/by/3.0/es/deed.en> 